\title{
When a black olive kernel causes SBO: first comparison of $\mathrm{CT}$ acquisition
}

\author{
Halil Yildiz, ${ }^{1}$ Olivier Dewit, ${ }^{2}$ Etienne Danse ${ }^{3}$
}

'Department of Medecine Interne, Cliniques Universitaires Saint-Luc, Bruxelles, Belgium ${ }^{2}$ Department of Gastroenterology, Cliniques Universitaires Saint-Luc, Bruxelles, Belgium ${ }^{3}$ Department of Radiology, Cliniques Universitaires SaintLuc, Bruxelles, Belgium

\section{Correspondence to}

Dr Halil Yildiz,

Halil.yildiz@uclouvain.be, h_tur. bel@hotmail.com

Accepted 30 May 2017

\section{DESCRIPTION}

A man aged 24 years presented with acute abdominal pain since 2 days. His past medical history was unremarkable. On physical examination, the abdomen was tender, soft and tympanic to percussion, with absent bowel sounds. CT of the abdomen revealed imaging signs indicating mechanical small bowel obstruction (SBO) related to ileal wall thickening (figure 1A) and to the presence of an alimentary fragment (an olive with its stone, one of the favourite foods of the patient) (figure 1A). The nature of the foreign body causing the SBO was suspected by the detailed history taking of the patient's alimentary habits. To confirm this diagnosis, a CT acquisition (figure 1B) of fresh olives (figure 1C) was made and the picture was compared with the patient images.

After conservative medical management, the patient completely recovered and underwent an ileocolonoscopy (figure 2A and B) with biopsy, which showed Crohn's disease of the terminal ileum. Usually, inflammatory bowel disease presents with diarrhoea, bloody stools, abdominal pain and weight loss but occlusion due to foreign body is rare. Most ingested foreign bodies are conveyed safely through the gastrointestinal tract and are occasionally complicated by bowel obstruction. This complication is very rare with olives. ${ }^{1}$ This
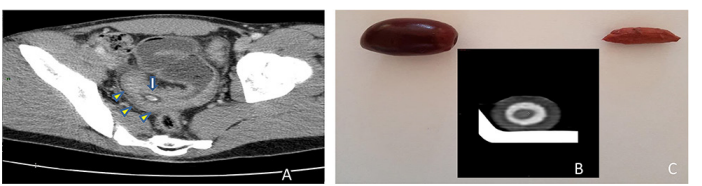

To cite: Yildiz H, Dewit $\mathrm{O}$, Danse E. BMJ Case Rep Published Online First: [please include Day Month Year]. doi:10.1136/bcr-2017220795
Figure 1 (A) Pelvic small bowel dilated loop with an ileal wall thickening (Crohn's disease, yellow arrow) and entrapment of an olive with its stone (white arrow). (B) $\mathrm{CT}$ acquisition of a black fresh olive in a pot. (C) Fresh olive and its kernel.

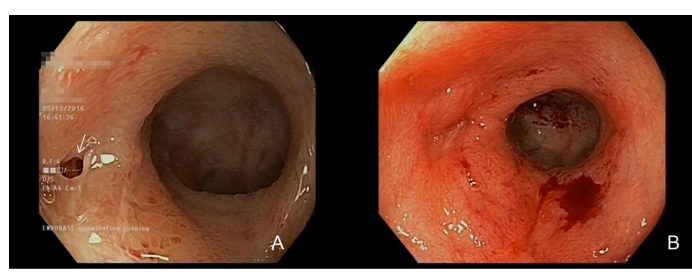

Figure 2 (A) lleoscopy showing narrowing of the terminal ileum and fibrotic aspect with scarred mucosa. Presence of a fistula orifice in the lower left part of the figure (arrow). (B) lleoscopy showing mild erythema, single superficial ulcer and presence of blood (due to the contact with the endoscope).

is also the first time that CT acquisition of a fresh olive has been compared with patient images.

\section{Learning points}

Small bowel obstruction (SBO) related to olive kernel is rare and when a patient comes with SBO, physician should always look for an underlying disease (eg, inflammatory bowel disease, cancer, lymphoma).

Contributors Professor ED helped us in understanding the $\mathrm{CT}$ acquisition. Dr YH took care of the patient and managed this patient. They contributed equally to the writing of this paper. Dr OD carried out the colonoscopy and is the gastroenterologist now taking care of the patient.

Competing interests None declared.

Patient consent Obtained.

Provenance and peer review Not commissioned; externally peer reviewed.

(c) BMJ Publishing Group Ltd (unless otherwise stated in the text of the article) 2017. All rights reserved. No commercial use is permitted unless otherwise expressly granted.

\section{REFERENCES}

1 Shedda S, Frizelle F. Images in clinical medicine. crohn's disease and an olive. N Engl J Med 2006;355:e22. 
Copyright 2017 BMJ Publishing Group. All rights reserved. For permission to reuse any of this content visit http://group.bmj.com/group/rights-licensing/permissions.

BMJ Case Report Fellows may re-use this article for personal use and teaching without any further permission.

Become a Fellow of BMJ Case Reports today and you can:

- Submit as many cases as you like

- Enjoy fast sympathetic peer review and rapid publication of accepted articles

Access all the published articles

- Re-use any of the published material for personal use and teaching without further permission

For information on Institutional Fellowships contact consortiasales@bmjgroup.com

Visit casereports.bmj.com for more articles like this and to become a Fellow 